\title{
Experimental advances in understanding allergic airway inflammation
}

\section{Christine M. Deppong1, Jonathan M. Green²}

${ }^{I}$ Department of Internal Medicine, Washington University School of Medicine, 660 South Euclid Ave, Box 8052, St. Louis, MO 63110, ${ }^{2}$ Division of Pulmonary and Critical Care Medicine, Department of Internal Medicine, Washington University School of Medicine, 660 S. Euclid Ave, Box 8052, St Louis, MO 63110

\section{TABLE OF CONTENTS}

\section{Abstract}

2. Introduction

3. Chemokines and Chemoattractants in T cell Migration into the Lung

4. T Lymphocyte Inhibitory Receptors and Allergic Airway Inflammation

4.1. CTLA4

4.2. $P D-L 1, P D-L 2$, and $P D-1$

4.3. BTLA and HVEM

5. Regulatory T cells and Allergic Airway Inflammation

5.1. Regulatory T cells in murine models of allergic airway inflammation

6. Conclusion

5.2. Regulatory $T$ cells in human asthma

7. Acknowledgements

8. References

\section{ABSTRACT}

Asthma is largely an inflammatory disease, with the development of $\mathrm{T}$ cell mediated inflammation in the lung following exposure to allergen or other precipitating factors. Currently, the major therapies for this disease are directed either at relief of bronchoconstriction (ie betaagonists) or are non-specific immunomodulators (ie, corticosteroids). While much attention has been paid to factors that regulate the initiation of an inflammatory response, chronic inflammation may also be due to defects in regulatory mechanisms that limit or terminate immune responses. In this review, we explore the elements controlling both the recruitment of $\mathrm{T}$ cells to the lung and their function. Possibilities for future therapeutic intervention are highlighted.

\section{INTRODUCTION}

Asthma is a chronic inflammatory disease of the airways affecting approximately 23 million Americans. Exacerbations are often triggered by inhalation of environmental agents that precipitate an inflammatory response, leading to the hallmark symptoms of airway hyperresponsiveness and excess mucous production. Thus, understanding mechanisms that control inflammatory responses in vivo are key to understanding the pathogenesis of asthma.

Murine models have been an important tool in dissecting the pathogenesis of asthma as they recapitulate some of the key features of the disease, including a characteristic CD4-dependent Th2-mediated immune 
response (1-5). In this review we will explore current therapies aimed at regulation of $\mathrm{T}$ cell function and other targets that may promote the resolution of allergic airway inflammation, comparing and contrasting data from murine model systems with that obtained from human studies.

Inflammation can be characterized by three distinct phases: (a) initiation, (b) effector and (c) resolution. Regulation and manipulation of the initiation and effector phases has been the subject of intense research resulting in many new therapies for immunologically based disorders. More recently, increased emphasis has been placed on understanding how immune responses are terminated, with the hope of developing new therapeutic targets (6-9). Such an approach may be beneficial in the treatment of asthma, as patients are typically encountered only after initial sensitization, limiting the ability to intervene at earlier phases.

Both activating and inhibitory receptors modulate the $\mathrm{T}$ cell response throughout the inflammatory response. For example, we and others have shown in a murine model that engagement of CD28 and other activating receptors such as Inducible Costimulator (ICOS) are required to initiate and maintain allergic airway inflammation (3, 10-12). Inhibitory receptors including Cytotoxic T-lymphocyte antigen 4 (CTLA4), programmed death receptor (PD-1) and $\mathrm{B}$ and $\mathrm{T}$ lymphocyte attenuator (BTLA) function after initial activation, determining the intensity and duration of inflammation $(6,8,13-14)$. Thus the persistent inflammation observed in asthmatic patients could potentially be due to either aberrant initial $\mathrm{T}$ cell activation and persistent positive signaling driving inflammation, or alternatively due to a failure of the normal homeostatic mechanisms that govern the resolution of inflammation.

\section{CHEMOKINES AND CHEMOATTRACTANTS IN T CELL MIGRATION INTO THE LUNG}

The recruitment of $\mathrm{T}$ cells to the lung is an essential early step in allergic lung inflammation. This process is regulated by chemokines, lipid chemoattractants, and their ligands expressed both on $\mathrm{T}$ lymphocytes and by parenchymal cells of the lung. These same classes of molecules are important during the resolution phase of inflammation, coordinating the egress of $\mathrm{T}$ lymphocytes out of the lung. Chemokines and chemoattractants have been the subject of extensive studies (15-18). Here we will specifically review the chemokines and chemoattractants which are important for $\mathrm{T}$ cell migration in murine models of allergic airway inflammation. Targeting of these molecules is a possible strategy for limiting allergic airway inflammation by altering cell trafficking.

CCR1 is a chemokine receptor expressed on multiple cell types, including: neutrophils, monocytes, lymphocytes, and eosinophils. It binds three chemokines: macrophage inflammatory protein-1-alpha (MIP-1-alpha, CCL3), regulated upon activation, normal T-cell expressed and secreted (RANTES, CCL5), and monocyte specific chemokine -3 (MCP-3, CCL7). There is conflicting data as to the importance of this chemokine receptor in airway inflammation. In comparison to wild type controls, CCR1- deficient mice had decreased Th2 cytokines and airway remodeling following challenge with Aspergillus fumigates, although no difference in airway hyperresponsiveness or cell composition of the bronchoalveolar lavage (BAL) was observed (19). In contrast, using CCR1 antagonist in wild type mice resulted in a decrease in airway hyperresponsiveness and no change in cytokine production after challenge (20). Thus, the importance of this pathway remains unclear.

CCR 3 and CCR4 are Th2 associated chemokine receptors. CCR3 is essential for the recruitment of eosinophils to the lung during allergic airway inflammation (21-22). While not directly responsible for recruiting $\mathrm{T}$ cells to the lung, CCR3 may still be an important target in dampening airway inflammation because of its role in recruitment of eosinophils (23-24). Conflicting results exist when examining the relationship between CCR4 and allergic airway inflammation. Some studies using CCR4deficient animals (25) or antibodies against the ligand of CCR4, (26) led to decreases in eosinophilia and Th2 cytokines in the BAL. However, in other studies, deficiency or blockade of CCR4 did not affect allergic airway inflammation (27-28). Interestingly, CCR4 is also expressed on allergen-specific regulatory $\mathrm{T}$ cells (Tregs) and may modulate inflammation via these cells (29). Using two adoptive transfer models, Mikhak et al demonstrated that CCR4 expression on Th2 cells was important for homing to the lung and inflammation independent of its expression on Tregs (30). However, this study did not examine the role of CCR4 on the trafficking of Tregs to the lungs. Thus, while CCR4 may be important for recruitment of Th2 lymphocytes during allergic airway inflammation, its function on Tregs will need to be clarified prior to therapeutic targeting.

CCR6, which binds CCL20, is expressed on immature dendritic cells, B cells, and memory T cells (3133). Acutely after allergen challenge, CCR6 and CCL20 were increased in the lung and draining lymph nodes (17). Further supportive of a role for CCR6, mice deficient in the receptor have decreased serum IgE, airway resistance, eosinophilia, IL-5, and fewer CD4+ T cells and B220+ B cells, in the lung following challenge (34). Another group has shown that deficiency of TNF-related apoptosisinducing ligand (TRAIL) leads to a decrease in CCL20 production, resulting in fewer myeloid dendritic cells (mDC) and memory T cells recruited through CCR6 and a concomitant decrease in airway inflammation (35).

Natural Killer (NK) cells, B cells and activated T cells all express CXCR3 (36). Though upregulated in mice following allergen challenge, (37) CXCR3 deficiency had no effect on the migration of Th2 cells to the lung (30). CXCR3 and its ligands, CXCL9 and CXCL10, have been associated predominantly with Th1 responses and explored as a potential mechanism to skew $\mathrm{T}$ cell populations in the lungs towards a Th1 response as opposed to a Th2 response. Using a neutralizing antibody, Thomas et al showed that loss of CXCL9 caused a decrease in CXCR3 expressing $\mathrm{T}$ cells, but also led to increased inflammation (38). Conversely, addition of exogenous CXCL9 reduced 
inflammation and production of Th2 cytokines (38). Manipulation of CXCL10 has led to conflicting results (3941). Thus, the effect of manipulation of this pathway on airway inflammation is difficult to predict and likely dependent on the specifics of the inflammatory response.

Lipid mediators also regulate the trafficking of cells to the lung. BLT1 is found on Th1 and Th2 cells and binds leukotriene B4 (LTB4). Mice deficient in BLT1 have fewer Th2 cells and altered kinetics of neutrophil and eosinophil recruitment to the airways (42-43). Prostaglandin D2 (PGD2) binds CRTh2, also known as DP2, which is expressed on Th2 lymphocytes, neutrophils and eosinophils, and has been associated with allergic inflammation. Activation of CRTh2 through the agonist 13,14-dihydro-15-keto- $\mathrm{PGD}_{2}$, resulted in increased eosinophilia in the BAL after allergen challenge $(18,44)$. However, somewhat discrepant results have been reported in the analysis of CRTh2 deficient mice. Deletion of CRTh2 resulted in decreased allergic skin inflammation, while in an airway model, enhanced eosinophilia and inflammatory cytokine production was observed (45-46). CRTh2 is found exclusively on Th2 cells in humans, while it can be expressed on both Th1 and Th2 cells in mice. Nonetheless, various small molecules antagonists to CRTh2 have been successfully tested in murine models and result in attenuation of allergic airway inflammation, suggesting this may be a viable therapeutic strategy (47-49).

3.1. The role of chemokines and chemoattractants in human asthmaStudies on humans with asthma have suggested an important role for chemokines and chemoattractants. Expression of the ligands for CCR3, CCR4, CCR5, CXCR1/2, CXCR3, and CRTh2 has been observed, suggesting that these chemoattractants play a role in both normal homeostasis as well as recruiting $\mathrm{T}$ lymphocytes to the lung in response to inflammation (5056). Here we briefly review the role of these pathways on $\mathrm{T}$ cell migration to the lung in human asthma (Figure 1).

In humans, CCR3 is expresssed on multiple cell types including eosinophils, neutrophils, and Th2 cells (57). The expression of the chemokine eotaxin, the ligand of CCR3, is found to be increased in the airways of asthmatics (58-60). It has been hypothesized that CCR3 contributes to the migration of $\mathrm{Th} 2$ cells to the lungs during asthma and may therefore make a good therapeutic target. CCR3 antagonists have been used by a number of groups in allergic airway inflammation models in mice and nonhuman primates. These antagonists have effectively blocked eosinophil, neutrophil, and lymphocyte migration into the lungs of these animals (61-64). Further studies are needed to understand their potential efficacy in humans.

Like CCR3, CCR4 is a Th2 associated chemokine receptor. CCR4 binds the chemokines CCL17 and CCL22, which are both found to be upregulated in the airway epithelial cells of asthmatics after allergen challenge (50, 65-66). Multiple studies have demonstrated CCR4 expression on $\mathrm{T}$ cells in asthmatics isolated from both the blood and the airways (67). Furthermore, using a CCR4 antagonist, it has been demonstrated that ex vivo allergen stimulated bronchial biopsies resulted in CCR4-dependent $\mathrm{T}$ cell chemotaxis. Interestingly, corticosteroid use in asthmatics has been shown to reduce the number of CCR4+ $\mathrm{T}$ cells (68). It should be noted that human Tregs also express CCR4 (69). As will be discussed later in this review, Tregs may be important for controlling allergic airway inflammation, and therefore any therapies targeting CCR4 will have to take into account potential effects on Tregs

Little is known about the role of CRTh2 in human asthma. It is well established, however, that the lipid mediator PGD2, which binds to CRTh2, is elevated in asthmatic patients (70). One study reports a significant difference in the percentage of CRTh2+ T cells in the BAL of asthmatics versus normal patients, however the percentage of cells expressing this receptor was low (71). Engagement of CRTh2 on Th2 cells by PGD2 induced cell migration (72) and stimulation of human Th2 cells in vitro with the CRTh2 agonist 13,14-dihydro-15-keto-PGD2 induced Th2 type cytokine production (73).

Manipulation of the migration of $\mathrm{T}$ lymphocytes into and/or out of the lung tissue provides an attractive potential for the development of new therapeutic reagents for asthma and other inflammatory diseases. By affecting the rate or ability of $\mathrm{T}$ lymphocytes to traffic to the lung, one should affect the overall evolution of the inflammatory response and thereby interrupt disease pathogenesis. While conflicting results in pre-clinical studies remain the rule, some potential drugs have been shown to have beneficial effects in animal models, although their effect in humans remains to be seen (47-49). Targeting individual chemokines, chemoattractants, and their ligands may allow for possible intervention that could affect only a subset of $\mathrm{T}$ cells. However, unintended immune suppression or other detrimental side effects remain a possibility.

\section{T LYMPHOCYTE INHIBITORY RECEPTORS AND ALLERGIC AIRWAY INFLAMMATION}

Specific receptor mediated pathways inhibit both the initiation of $\mathrm{T}$ cell function, as well as promote the resolution of an established inflammatory response. The major inhibitory receptors on $\mathrm{T}$ cells include: CTLA4 (CD152), PD-1 (CD279), and BTLA (CD272). Aberrant expression or function of these pathways could lead to a failure to normally limit ongoing $\mathrm{T}$ cell activation, and thereby result in chronic inflammation. We will more fully explore the function of each of these ligands and their possible roles in allergic airway inflammation.

\subsection{CTLA4}

CTLA4 is a homolog of CD28 and has been shown to inhibit $\mathrm{T}$ cell function. Not expressed on resting $\mathrm{T}$ cells, CTLA4 expression on the cell surface is detected following initial activation. Both CD28 and CTLA4 are able to bind B7-1 (CD80) and B7-2 (CD86) on antigen presenting cells (APCs). However, CTLA4 binds both B7 molecules with a higher affinity than $\mathrm{CD} 28$. A critical role for CTLA4 in the regulation of $\mathrm{T}$ cell activation and the maintenance of $\mathrm{T}$ cell-mediated immune responses has 


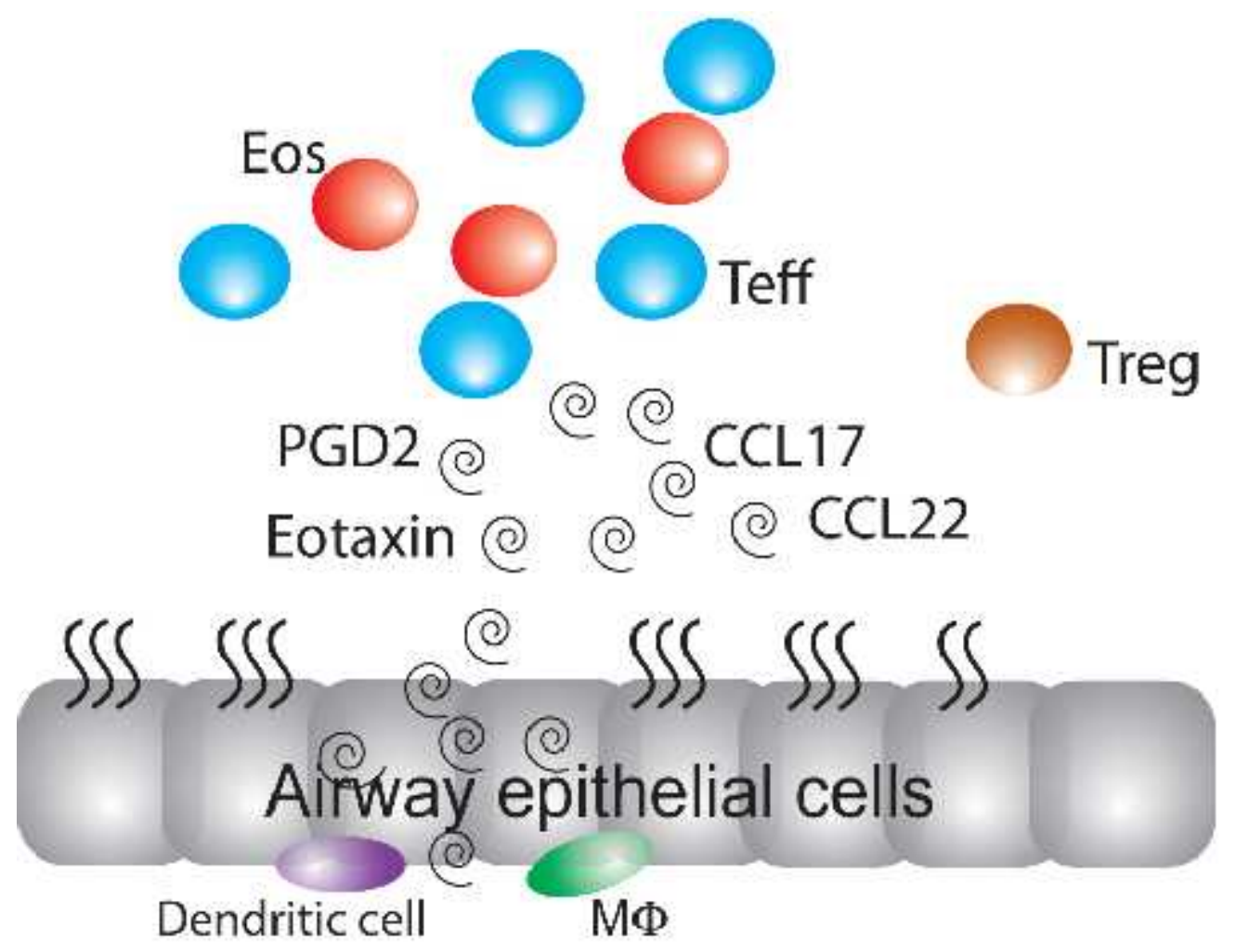

Figure 1. Migration of T lymphocytes to the airways. In response to allergen challenge, airway epithelial cells and other cells in the lungs upregulate production of chemokines. These chemokines (black swirls) then attract Th2 cells (blue) to the lungs in order to clear the allergen, and this results in inflammation. Also attracted to the lungs by some of the same cytokines are eosinophils (red), which exacerbates the inflammation, and regulatory $\mathrm{T}$ cells (brown), which may be one mechanism by which inflammation can be resolved.

been demonstrated. CTLA4-deficient mice display a rapid development of severe lymphoproliferation, which results in lethality at 3-4 weeks of age (74-75). In vitro, T cells deficient in CTLA4 have increased proliferation and cytokine production. The role of this inhibitory receptor during allergic airway inflammation has been studied. Treatment of mice with a CTLA4 blocking antibody during sensitization led to increased eosinophil infiltrates and antigen specific IgE production (76). However, it was also shown that blockade of CTLA4 during only the challenge phase resulted in no change in the inflammation. These results suggest that CTLA4 may function to regulate early responses in naïve $\mathrm{T}$ cells, but may not be as critical for regulation of already activated $\mathrm{T}$ cells in allergic airway inflammation.

CTLA4Ig is a fusion protein of an Fc fragment and the extracellular portion of CTLA4. It is able to effectively block CD28 ligation by B7 molecules through competitive inhibition. Studies in which CTLA4Ig was administered before and during antigen challenge, consistently prevented allergic airway inflammation, measured by both eosinophilic infiltration and cytokine production (77-82). While showing that the activation of allergic airway inflammation is dependent on the B7:CD28 signaling pathway, these studies did not address whether or not CTLA4Ig could be used to ablate already established inflammation. Using a model in which mice are deficient in both CD28 and the inhibitory receptor, BTLA, we established that CTLA4Ig can not only prevent inflammation, but can promote the resolution of established airway inflammation. Surprisingly, we found that this is through a mechanism independent of CTLA4Ig's ability to prevent CD28 engagement of B7-1 and B7-2 (83). While there is currently no literature on the use of CTLA4Ig in humans as a therapeutic drug during asthma, it is currently approved for use in rheumatoid arthritis (abatacept, Orencia $^{\mathrm{TM}}$, Bristol Myers Squibb Corporation) (84).

\subsection{PD-L1, PD-L2 and PD-1}

PD-1 is an inhibitory receptor that is a member of the CD28 superfamily (85). Activated $\mathrm{B}, \mathrm{T}$, and myeloid cells express PD-1 (86-87). In mice, deficiency of PD-1 leads to a lupus-like autoimmune disease, which suggests an inhibitory role for PD-1 in the immune response in vivo (87). Analogous to CD28, PD-1 has two ligands B7-H1 (PD-L1) and B7-DC (PD-L2) which have differing expression patterns. PD-L1 is expressed on $\mathrm{B}$ and $\mathrm{T}$ lymphocytes, dendritic cells, macrophages, and nonlymphoid cells (88-89). In contrast, PD-L2 is expressed only on macrophages and dendritic cells. To date, PD-L1 and PD-L2 have been implicated in both the activation (90) and inhibition (91) of $\mathrm{T}$ cell function. While these contradictory results have not been fully explained, they 
could be due to the presence of an ITSM in the cytoplasmic tail of PD-1. This switch domain may result in either activating or inhibitory signaling. Alternatively there may be a second receptor for PD-L1 and PD-L2 (92). Interestingly, it has recently been demonstrated that PD-L1 is important for the maintenance of some Treg populations (93). Expression and engagement of PD-L1 on this suppressive cell type may explain some of the existing contradictory results from different studies exploring the role of the PD-1 in allergic airway inflammation. Studies examining this pathway in allergic airway inflammation, have suggested that PD-L2 is upregulated during such inflammation (94). It was also shown that administration of the fusion protein PD-L2-Fc resulted in increased lung inflammation, suggesting that the binding of this protein to PD-1 may be activating in nature. Alternatively, the PDL2-Fc may be binding to a ligand that is currently unidentified.

Other studies have found that treatment with PDL2 neutralizing antibodies at the time of allergen challenge resulted in decreased Th1 and increased Th2 cytokine production, accompanied by an increase in eosinophilia and airway hyperreactivity (95). These results suggest that PD1/PD-L2 signaling is critical for the downregulation of allergic lung inflammation. Though these two studies used similar allergic airway models, the results were contradictory. One suggests that PD-1/PD-L2 signaling is important for activating allergic airway inflammation, while the other suggests that the receptor/ligand binding is important for termination of such inflammation. Thus, further studies are required to fully elucidate the function of the PD-1/PD-L1/PD-L2 pathway in the regulation of allergic airway inflammation.

\subsection{BTLA and HVEM}

BTLA is an inhibitory receptor that is a member of the Ig-superfamily (96). BTLA can be found on B and T lymphocytes, macrophages, dendritic cells, and NK cells (96-97). It is expressed at higher levels on activated versus naïve T cells (97-98). The cytoplasmic tail of BTLA has an ITIM, ITSM, and a third tyrosine containing motif. The ITIM and ITSM are associated with SHP-1 and SHP-2, while the third motif has been shown to bind Grb-2 $(96,99-$ 100). The presence of the ITIM and ITSM motifs suggests that BTLA is an inhibitory molecule. Studies have shown that engagement of BTLA is able to partially inhibit IL-2 secretion and BTLA-deficient $\mathrm{T}$ lymphocytes exhibit increased proliferation (96). In a murine model of multiple sclerosis, experimental autoimmune encephalomyelitis (EAE), BTLA-deficiency led to increased severity of and prolonged disease (96). Further suggesting an inhibitory role, in vivo studies have shown that BTLA-deficient mice reject partially mismatched cardiac allografts faster than their wild type counterparts (101).BTLA has been shown to also have an inhibitory role in allergic airway inflammation. Mice deficient in BTLA exhibit prolonged inflammation after allergen challenge (6). Further, it has been demonstrated that BTLA is responsible for increased Th2 cytokines during allergic airway inflammation (102). In contrast to all of the studies suggesting an inhibitory role for BTLA, one recent study suggests an activating function for this molecule. In a graft versus host disease (GVHD) model, BTLA ${ }^{-/}$donor cells that were transferred into wild type hosts, failed to survive (103). Similar effects were demonstrated using an antibody that blocks BTLA binding to its ligand. Taken together, these studies suggest a complicated role for BTLA in the immune response.

Interestingly, the ligand of BTLA, herpesvirus entry mediator (HVEM), is a member of the tumor necrosis factor receptor (TNFR) superfamily (104-105). Expression of HVEM on T cells is fluctuating; it is high on naïve cells, downregulated upon activation, and then upregulated near the end of the activation phase (106). HVEM is also able to bind to LIGHT and interactions with this receptor result in a costimulatory signal for $T$ cells (107). Conversely, engagement of BTLA by HVEM leads to inhibition of T cell proliferation (105). Targeting the interactions between BTLA and HVEM as a means for controlling allergic airway inflammation will need to be carefully monitored. Not only does signaling occur through both molecules, but the ability of BTLA's ligand, HVEM, to bind the costimulatory molecule LIGHT will provide for potentially complicated outcomes.

Expression of the ligands of $\mathrm{T}$ cell inhibitory receptors has been detected in lung tissue. Expression of CD80, CD86, PD-L1, and PD-L2, can be induced on airway epithelial cells from humans (108-109). Furthermore, in mice CD86 expression is upregulated in alveolar macrophages, and expression of CD86 and PD-L1 is upregulated in lung tissue after allergen challenge (110111). Interaction between the inhibitory receptors on $T$ cells and their ligands in the lung tissue under normal homeostatic conditions may lead to the resolution of inflammation (Figure 2). Use of a drug, such as CTLA4Ig, may be able to resolve this aberrant airway inflammation.

Of these three major inhibitory receptors of $\mathrm{T}$ cell activation, CTLA4 is currently the most promising target for resolution of allergic airway inflammation. Both PD-1 and BTLA are found on multiple cell types, as are their ligands. More research must be completed in order to determine their mechanisms of action during allergic airway inflammation and if monoclonal antibodies against these ligands would be able to inhibit inflammation. Particularly agonists of these inhibitory pathways may help to speed the resolution of inflammation.

\section{REGULATORY T CELLS AND ALLERGIC AIRWAY INFLAMMATION}

Tregs are a subset of $\mathrm{T}$ lymphocytes that can suppress immune responses. The most well characterized subset of these cells are CD4+ T cells, with high levels of CD25 expressed on their surface and expression of the transcription factor Foxp3. Not only may these cells play an important role in immunological tolerance within the lungs of normal individuals, but their role as an effector cell in limiting allergic airway inflammation has been explored. Tregs may control inflammation through suppression of effector T cells, APCs, or both. Suppression by Tregs has been shown in vitro through production of IL- 


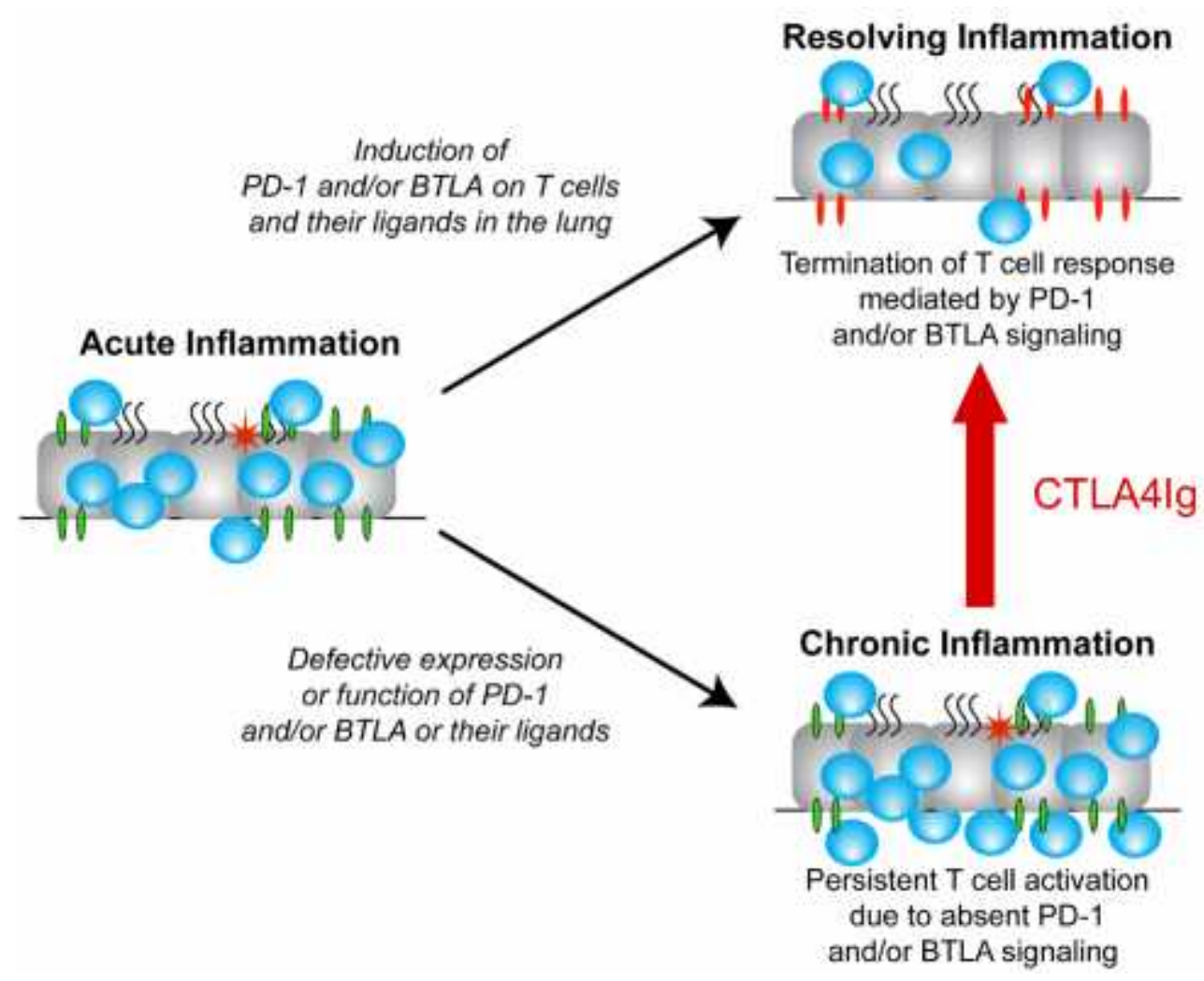

Figure 2. Resolution of the inflammatory response. Following activation of inflammation within the airways, inhibitory receptors and ligands are upregulated on T lymphocytes and other cells in the lung environment. Engagement of these inhibitory receptors leads to resolution of inflammation. When there is defective expression or function of these receptors, chronic inflammation may ensue. This chronic inflammation may then be resolved through the use of the drug CTLA4Ig.

10 and through the inhibitory receptors CTLA4, PD-1, and BTLA (112). Optimization of the number or function of these suppressive cells may be a potential therapeutic target in allergic airway inflammation. Though the exact mechanisms of action remain unclear, we will briefly review here, the role of Tregs in limiting allergic airway inflammation.

\subsection{Regulatory $T$ cells in murine models of allergic airway inflammation}

In murine models, it has been shown that the number of Foxp3+ cells increases during airway inflammation, suggesting that it may be a natural mechanism by which organisms limit or resolve lung inflammation (113) . Depletion of Tregs prior to antigen challenge can lead to increased inflammation, airway hyperresponsiveness, eosinophilia, and Th2 cytokine production (114-115). Conversely, adoptive transfer of Tregs inhibits airway inflammation (116-119). While these studies have shown the importance of Tregs in regulating allergic airway inflammation, there is no consensus on the precise mechanism of action. Pathways implicated by these studies include, PD-1, increased pulmonary mDCs, as well as IL-10 dependent and -independent pathways.

Interestingly, some evidence suggests that current therapies for asthma may work in part by effecting
Tregs. Treatment of mice with corticosteroids and IL-2 led to an increase in Foxp3+ Tregs in spleens which were able to suppress proliferation of $\mathrm{CD} 4+\mathrm{CD} 25-\mathrm{T}$ cells in vitro (120). Vitamin D can inhibit proinflammatory responses and has recently been used in combination with glucocorticoids in order to determine their combined effect on Tregs. In vitro stimulation of CD4+ $\mathrm{T}$ cells with Vitamin D and dexamethasone led to production of Tregs, determined by both the production of IL-10 and the ability to prevent EAE in vivo (121).

\subsection{Regulatory $T$ cells in human asthma}

Tregs have been implicated as a possible suppressor of allergic airway inflammation in humans. In atopic children and adults, CD4+CD25hi T cells isolated from the blood have a reduced ability to suppress CD4+CD25- cells, as compared to controls (122-127). While comparison of nonatopic controls with asthmatics showed no significant difference in the percentages of CD4+CD25hi T cells in the blood, a decrease of Foxp3 expression was shown (126). Furthermore, one study suggested there may be a decrease in Tregs in the broncoalveolar lavage fluid (BALF) of asthmatic children (128). Another study comparing asthmatic and healthy individuals showed a greater number of Tregs in healthy individuals, while asthmatics had a higher percentage of Th2 cells (129). When these IL-10 producing Tregs, which 
expressed CTLA4, PD-1 and IL-10R, were expanded ex vivo and cultured with peripheral blood mononuclear cells (PBMCs), there was an antigen-specific suppression of proliferation.

The study of Tregs in asthmatics is complicated by the prevalent use of corticosteroids, which may alter Tregs by affecting both IL-10 production and Foxp3 expression (122-125). In one study where patients used corticosteroids, moderate/severe asthmatics had an increase in CD4+Foxp3+ cells in the BAL as compared to healthy adults (130). The authors attributed this increase to a combination of the use of corticosteroids and increased airway inflammation. A study of pediatric patients with asthma and allergic rhinitis found there to be a lower percentage of CD4+CD25hi cells in the blood, though Foxp3 mRNA levels were increased as compared to control patients (131). Again, in this study, these patients received steroids, which may alter Foxp3 expression. Similarly, Hartl et al demonstrated that administration of corticosteroids increased the number of CD4+CD25hi cells in the BALF and the suppressive capabilities of these cells (128). In another study, the numbers of CD4+CD25hiFoxp3+ cells in the peripheral blood were found to be the same between asthmatics and control patients (132). However, the decreased expression of Foxp3 in the CD4+CD25hi $\mathrm{T}$ cells of asthmatics patients was less pronounced in those treated with glucocorticoids. Additionally, Vitamin D may influence the generation of IL-10 producing Tregs, an effect that may synergize with glucocorticoids $(121,133)$. It has been proposed that Vitamin D may increase the effectiveness of corticosteroid therapy in some steroid resistant asthmatics (133-135). Thus, Tregs have an important, if not yet well defined, role in regulating the asthmatic phenotype.

\section{CONCLUSION}

Asthma is a chronic inflammatory disease of the airways. In this review we have explored three possible categories of targets for controlling asthma and its debilitating symptoms. Though many similarities exist between murine models of allergic airway inflammation and human asthma, there are differences in expression and function of individual molecules which are important for the pathogenesis of this disease. The first set of possible targets reviewed includes chemoattractant receptors which regulate $\mathrm{T}$ cell trafficking into the lung during an immune response. Currently, it seems that targeting the trafficking of T lymphocytes during allergic airway inflammation may provide the most complicated strategies of the three categories discussed in this review. All of the receptors discussed are associated with multiple cell types and in many locations. To date, no lung-specific chemoattractant and receptor pair have been identified. Targeting any individually known molecule important for the trafficking of $\mathrm{T}$ cells may lead to a variety of outcomes.

The second category of targets reviewed was inhibitory receptors expressed on $\mathrm{T}$ cells. As with targeting $\mathrm{T}$ cell trafficking, a central issue with targeting these inhibitory receptors is that they are general $\mathrm{T}$ cell receptors and may dampen other aspects of the immune system, with the accompanying potential for deleterious outcomes. Last, we examined the function of Treg cells as a mechanism for ablating allergic airway inflammation. Use of Tregs in this capacity encompasses aspects of both the trafficking of these cells into the lungs and inhibitory ligands as possible mechanisms of suppression. The potential ability of glucocorticoids to increase the numbers and function of Tregs, including through enhanced upregulation of inhibitory receptors, may provide a new clinical endpoint for optimizing the use of already approved treatments for asthma. Studies altering the way that glucocorticoids are administered to optimize effects on Tregs may be key to understanding "natural" suppression of allergic airway inflammation. Though the three main topics reviewed here are broad, they are all complicatedly intertwined. Studies of the trafficking of $\mathrm{T}$ cells, the mechanisms of $\mathrm{T}$ cell inhibitory receptors, and Tregs cells may lead to exciting new therapies to aid in the control of asthma.

\section{ACKNOWLEDGEMENTS}

The authors thank Jonathan Boomer and Traci Bricker for discussion and review of the manuscript.

\section{REFERENCES}

1. S. H. Gavett, X. Chen, F. Finkelman and M. Wills-Karp: Depletion of murine CD4+ $\mathrm{T}$ lymphocytes prevents antigen-induced airway hyperreactivity and pulmonary eosinophilia. Am J Respir Cell Mol Biol, 10(6), 587-93 (1994)

2. J. A. Gonzalo, C. M. Lloyd, L. Kremer, E. Finger, A. C. Martinez, M. H. Siegelman, M. Cybulsky and J. C. GutierrezRamos: Eosinophil recruitment to the lung in a murine model of allergic inflammation. The role of $\mathrm{T}$ cells, chemokines, and adhesion receptors. J Clin Invest, 98(10), 2332-45 (1996)

3. S. L. Kimzey, P. Liu and J. M. Green: Requirement for $\mathrm{CD} 28$ in the effector phase of allergic airway inflammation. $J$ Immunol, 173(1), 632-40 (2004)

4. X. M. Li, B. H. Schofield, Q. F. Wang, K. H. Kim and S. K. Huang: Induction of pulmonary allergic responses by antigenspecific Th2 cells. J Immunol, 160(3), 1378-84 (1998)

5. M. Wills-Karp: Immunologic basis of antigen-induced airway hyperresponsiveness. Annu Rev Immunol, 17, 255-81 (1999)

6. C. Deppong, T. I. Juehne, M. Hurchla, L. D. Friend, D. D. Shah, C. M. Rose, T. L. Bricker, L. P. Shornick, E. C. Crouch, T. L. Murphy, M. J. Holtzman, K. M. Murphy and J. M. Green: Cutting edge: $\mathrm{B}$ and $\mathrm{T}$ lymphocyte attenuator and programmed death receptor-1 inhibitory receptors are required for termination of acute allergic airway inflammation. $J$ Immunol, 176(7), 3909-13 (2006)

7. S. Dimeloe, A. Nanzer, K. Ryanna and C. Hawrylowicz: Regulatory $\mathrm{T}$ cells, inflammation and the allergic responseThe role of glucocorticoids and Vitamin D. J Steroid Biochem Mol Biol, 120(2-3), 86-95 (2010) 
8. L. M. Francisco, P. T. Sage and A. H. Sharpe: The PD-1 pathway in tolerance and autoimmunity. Immunol Rev, 236, 219-42 (2010)

9. K. V. Poojary, Y. C. Kong and M. A. Farrar: Control of Th2-mediated inflammation by regulatory T cells. Am J Pathol, 177(2), 525-31 (2010)

10. A. J. Coyle, S. Lehar, C. Lloyd, J. Tian, T. Delaney, S. Manning, T. Nguyen, T. Burwell, H. Schneider, J. A. Gonzalo, M. Gosselin, L. R. Owen, C. E. Rudd and J. C. Gutierrez-Ramos: The CD28-related molecule ICOS is required for effective $\mathrm{T}$ cell-dependent immune responses. Immunity, 13(1), 95-105 (2000)

11. J. A. Gonzalo, J. Tian, T. Delaney, J. Corcoran, J. B. Rottman, J. Lora, A. Al-garawi, R. Kroczek, J. C. Gutierrez-Ramos and A. J. Coyle: ICOS is critical for T helper cell-mediated lung mucosal inflammatory responses. Nat Immunol, 2(7), 597-604 (2001)

12. A. G. Tesciuba, S. Subudhi, R. P. Rother, S. J. Faas, A. M. Frantz, D. Elliot, J. Weinstock, L. A. Matis, J. A. Bluestone and A. I. Sperling: Inducible costimulator regulates Th2-mediated inflammation, but not Th2 differentiation, in a model of allergic airway disease. $J$ Immunol, 167(4), 1996-2003 (2001)

13. T. L. Murphy and K. M. Murphy: Slow down and survive: Enigmatic immunoregulation by BTLA and HVEM. Annu Rev Immunol, 28, 389-411 (2010)

14. C. E. Rudd, A. Taylor and H. Schneider: CD28 and CTLA-4 coreceptor expression and signal transduction. Immunol Rev, 229(1), 12-26 (2009)

15. P. C. Fulkerson, N. Zimmermann, L. M. Hassman, F. D. Finkelman and M. E. Rothenberg: Pulmonary chemokine expression is coordinately regulated by STAT1, STAT6, and IFN-gamma. J Immunol, 173(12), 7565-74 (2004)

16. W. R. Henderson, Jr., D. B. Lewis, R. K. Albert, Y. Zhang, W. J. Lamm, G. K. Chiang, F. Jones, P. Eriksen, Y. T. Tien, M. Jonas and E. Y. Chi: The importance of leukotrienes in airway inflammation in a mouse model of asthma. J Exp Med, 184(4), 1483-94 (1996)

17. N. W. Lukacs, D. M. Prosser, M. Wiekowski, S. A. Lira and D. N. Cook: Requirement for the chemokine receptor CCR6 in allergic pulmonary inflammation. J Exp Med, 194(4), 551-5 (2001)

18. Y. Shiraishi, K. Asano, T. Nakajima, T. Oguma, Y. Suzuki, T. Shiomi, K. Sayama, K. Niimi, M. Wakaki, J. Kagyo, E. Ikeda, H. Hirai, K. Yamaguchi and A. Ishizaka: Prostaglandin D2-induced eosinophilic airway inflammation is mediated by CRTH2 receptor. $J$ Pharmacol Exp Ther, 312(3), 954-60 (2005)

19. K. Blease, B. Mehrad, T. J. Standiford, N. W. Lukacs, S. L. Kunkel, S. W. Chensue, B. Lu, C. J. Gerard and C. M.
Hogaboam: Airway remodeling is absent in CCR1-/- mice during chronic fungal allergic airway disease. $J$ Immunol, 165(3), 1564-72 (2000)

20. K. J. Carpenter, J. L. Ewing, J. M. Schuh, T. L. Ness, S. L. Kunkel, M. Aparici, M. Miralpeix and C. M. Hogaboam: Therapeutic targeting of CCR1 attenuates established chronic fungal asthma in mice. Br J Pharmacol, 145(8), 1160-72 (2005)

21. A. A. Humbles, B. Lu, D. S. Friend, S. Okinaga, J. Lora, A. Al-Garawi, T. R. Martin, N. P. Gerard and C. Gerard: The murine CCR3 receptor regulates both the role of eosinophils and mast cells in allergen-induced airway inflammation and hyperresponsiveness. Proc Natl Acad Sci U S A, 99(3), 1479$84(2002)$

22. S. M. Pope, N. Zimmermann, K. F. Stringer, M. L. Karow and M. E. Rothenberg: The eotaxin chemokines and CCR3 are fundamental regulators of allergen-induced pulmonary eosinophilia. J Immunol, 175(8), 5341-50 (2005)

23. P. C. Fulkerson, C. A. Fischetti, M. L. McBride, L. M. Hassman, S. P. Hogan and M. E. Rothenberg: A central regulatory role for eosinophils and the eotaxin/CCR3 axis in chronic experimental allergic airway inflammation. Proc Natl Acad Sci U S A, 103(44), 16418-23 (2006)

24. W. Ma, P. J. Bryce, A. A. Humbles, D. Laouini, A. Yalcindag, H. Alenius, D. S. Friend, H. C. Oettgen, C. Gerard and R. S. Geha: CCR3 is essential for skin eosinophilia and airway hyperresponsiveness in a murine model of allergic skin inflammation. J Clin Invest, 109(5), 621-8 (2002)

25. J. M. Schuh, C. A. Power, A. E. Proudfoot, S. L. Kunkel, N. W. Lukacs and C. M. Hogaboam: Airway hyperresponsiveness, but not airway remodeling, is attenuated during chronic pulmonary allergic responses to Aspergillus in CCR4-/- mice. FASEB J, 16(10), 1313-5 (2002)

26. S. Kawasaki, H. Takizawa, H. Yoneyama, T. Nakayama, R. Fujisawa, M. Izumizaki, T. Imai, O. Yoshie, I. Homma, K. Yamamoto and K. Matsushima: Intervention of thymus and activation-regulated chemokine attenuates the development of allergic airway inflammation and hyperresponsiveness in mice. J Immunol, 166(3), 2055-62 (2001)

27. Y. Chvatchko, A. J. Hoogewerf, A. Meyer, S. Alouani, P. Juillard, R. Buser, F. Conquet, A. E. Proudfoot, T. N. Wells and C. A. Power: A key role for CC chemokine receptor 4 in lipopolysaccharide-induced endotoxic shock. J Exp Med, 191(10), 1755-64 (2000)

28. D. M. Conroy, L. A. Jopling, C. M. Lloyd, M. R. Hodge, D. P. Andrew, T. J. Williams, J. E. Pease and I. Sabroe: CCR4 blockade does not inhibit allergic airways inflammation. $J$ Leukoc Biol, 74(4), 558-63 (2003)

29. K. Saito, M. Torii, N. Ma, T. Tsuchiya, L. Wang, T. Hori, D. Nagakubo, N. Nitta, S. Kanegasaki, K. Hieshima, O. Yoshie, E. C. Gabazza, N. Katayama, H. Shiku, K. Kuribayashi and T. Kato: Differential regulatory function 
of resting and preactivated allergen-specific CD4+ CD25+ regulatory $\mathrm{T}$ cells in Th2-type airway inflammation. $J$ Immunol, 181(10), 6889-97 (2008)

30. Z. Mikhak, M. Fukui, A. Farsidjani, B. D. Medoff, A. M. Tager and A. D. Luster: Contribution of CCR4 and CCR8 to antigen-specific $\mathrm{T}(\mathrm{H}) 2$ cell trafficking in allergic pulmonary inflammation. J Allergy Clin Immunol, 123(1), 67-73 e3 (2009)

31. F. Liao, R. L. Rabin, C. S. Smith, G. Sharma, T. B. Nutman and J. M. Farber: CC-chemokine receptor 6 is expressed on diverse memory subsets of $\mathrm{T}$ cells and determines responsiveness to macrophage inflammatory protein 3 alpha. J Immunol, 162(1), 186-94 (1999)

32. C. A. Power, D. J. Church, A. Meyer, S. Alouani, A. E. Proudfoot, I. Clark-Lewis, S. Sozzani, A. Mantovani and T. N. Wells: Cloning and characterization of a specific receptor for the novel CC chemokine MIP-3alpha from lung dendritic cells. J Exp Med, 186(6), 825-35 (1997)

33. D. Yang, O. Chertov, S. N. Bykovskaia, Q. Chen, M. J. Buffo, J. Shogan, M. Anderson, J. M. Schroder, J. M. Wang, O. M. Howard and J. J. Oppenheim: Beta-defensins: linking innate and adaptive immunity through dendritic and T cell CCR6. Science, 286(5439), 525-8 (1999)

34. S. K. Lundy, S. A. Lira, J. J. Smit, D. N. Cook, A. A. Berlin and N. W. Lukacs: Attenuation of allergen-induced responses in CCR6-/- mice is dependent upon altered pulmonary T lymphocyte activation. J Immunol, 174(4), 2054-60 (2005)

35. M. Weckmann, A. Collison, J. L. Simpson, M. V. Kopp, P. A. Wark, M. J. Smyth, H. Yagita, K. I. Matthaei, N. Hansbro, B. Whitehead, P. G. Gibson, P. S. Foster and J. Mattes: Critical link between TRAIL and CCL20 for the activation of $\mathrm{TH} 2$ cells and the expression of allergic airway disease. Nat Med, 13(11), 1308-15 (2007)

36. W. W. Hancock: Chemokine receptor-dependent alloresponses. Immunol Rev, 196, 37-50 (2003)

37. Y. Suzaki, K. Hamada, T. Nomi, T. Ito, M. Sho, Y. Kai, Y. Nakajima and H. Kimura: A small-molecule compound targeting CCR5 and CXCR3 prevents airway hyperresponsiveness and inflammation. Eur Respir $J$, 31(4), 783-9 (2008)

38. M. S. Thomas, S. L. Kunkel and N. W. Lukacs: Regulation of cockroach antigen-induced allergic airway hyperreactivity by the CXCR3 ligand CXCL9. J Immunol, 173(1), 615-23 (2004)

39. B. D. Medoff, S. Y. Thomas and A. D. Luster: T cell trafficking in allergic asthma: the ins and outs. Annu Rev Immunol, 26, 205-32 (2008)

40. M. S. Thomas, S. L. Kunkel and N. W. Lukacs: Differential role of IFN-gamma-inducible protein $10 \mathrm{kDa}$ in a cockroach antigen-induced model of allergic airway hyperreactivity: systemic versus local effects. J Immunol, 169(12), 7045-53 (2002)

41. R. Wiley, K. Palmer, B. Gajewska, M. Stampfli, D. Alvarez, A. Coyle, J. Gutierrez-Ramos and M. Jordana: Expression of the Th1 chemokine IFN-gamma-inducible protein 10 in the airway alters mucosal allergic sensitization in mice. J Immunol, 166(4), 2750-9 (2001)

42. B. D. Medoff, A. M. Tager, R. Jackobek, T. K. Means, L. Wang and A. D. Luster: Antibody-antigen interaction in the airway drives early granulocyte recruitment through BLT1. Am J Physiol Lung Cell Mol Physiol, 290(1), L170-8 (2006)

43. A. M. Tager, S. K. Bromley, B. D. Medoff, S. A. Islam, S. D. Bercury, E. B. Friedrich, A. D. Carafone, R. E. Gerszten and A. D. Luster: Leukotriene B4 receptor BLT1 mediates early effector T cell recruitment. Nat Immunol, 4(10), 982-90 (2003)

44. I. Spik, C. Brenuchon, V. Angeli, D. Staumont, S. Fleury, M. Capron, F. Trottein and D. Dombrowicz: Activation of the prostaglandin D2 receptor DP2/CRTH2 increases allergic inflammation in mouse. J Immunol, 174(6), 3703-8 (2005)

45. E. Chevalier, J. Stock, T. Fisher, M. Dupont, M. Fric, H. Fargeau, M. Leport, S. Soler, S. Fabien, M. P. Pruniaux, M. Fink, C. P. Bertrand, J. McNeish and B. Li: Cutting edge: chemoattractant receptor-homologous molecule expressed on Th2 cells plays a restricting role on IL-5 production and eosinophil recruitment. J Immunol, 175(4), 2056-60 (2005)

46. T. Satoh, R. Moroi, K. Aritake, Y. Urade, Y. Kanai, K. Sumi, H. Yokozeki, H. Hirai, K. Nagata, T. Hara, M. Utsuyama, K. Hirokawa, K. Sugamura, K. Nishioka and M. Nakamura: Prostaglandin D2 plays an essential role in chronic allergic inflammation of the skin via CRTH2 receptor. $J$ Immunol, 177(4), 2621-9 (2006)

47. N. W. Lukacs, A. A. Berlin, K. Franz-Bacon, R. Sasik, L. J. Sprague, T. W. Ly, G. Hardiman, S. A. Boehme and K. B. Bacon: CRTH2 antagonism significantly ameliorates airway hyperreactivity and downregulates inflammation-induced genes in a mouse model of airway inflammation. Am J Physiol Lung Cell Mol Physiol, 295(5), L767-79 (2008)

48. L. Uller, J. M. Mathiesen, L. Alenmyr, M. Korsgren, T. Ulven, T. Hogberg, G. Andersson, C. G. Persson and E. Kostenis: Antagonism of the prostaglandin D2 receptor CRTH2 attenuates asthma pathology in mouse eosinophilic airway inflammation. Respir Res, 8, 16 (2007)

49. T. Ulven, J. M. Receveur, M. Grimstrup, O. Rist, T. M. Frimurer, L. O. Gerlach, J. M. Mathiesen, E. Kostenis, L. Uller and T. Hogberg: Novel selective orally active CRTH2 antagonists for allergic inflammation developed from in silico derived hits. J Med Chem, 49(23), 6638-41 (2006)

50. B. S. Bochner, S. A. Hudson, H. Q. Xiao and M. C. Liu: Release of both CCR4-active and CXCR3-active chemokines during human allergic pulmonary late-phase reactions. J Allergy Clin Immunol, 112(5), 930-4 (2003) 
51. S. T. Holgate, K. S. Bodey, A. Janezic, A. J. Frew, A. P. Kaplan and L. M. Teran: Release of RANTES, MIP-1 alpha, and MCP-1 into asthmatic airways following endobronchial allergen challenge. Am J Respir Crit Care Med, 156(5), 1377-83 (1997)

52. T. Kallinich, S. Schmidt, E. Hamelmann, A. Fischer, S. Qin, W. Luttmann, J. C. Virchow and R. A. Kroczek: Chemokine-receptor expression on $\mathrm{T}$ cells in lung compartments of challenged asthmatic patients. Clin Exp Allergy, 35(1), 26-33 (2005)

53. C. M. Lilly, H. Nakamura, O. I. Belostotsky, K. J. Haley, E. A. Garcia-Zepeda, A. D. Luster and E. Israel: Eotaxin expression after segmental allergen challenge in subjects with atopic asthma. Am J Respir Crit Care Med, 163(7), 1669-75 (2001)

54. J. J. Murray, A. B. Tonnel, A. R. Brash, L. J. Roberts, 2nd, P. Gosset, R. Workman, A. Capron and J. A. Oates: Release of prostaglandin D2 into human airways during acute antigen challenge. $N$ Engl $J$ Med, 315(13), 800-4 (1986)

55. R. E. Nocker, T. A. Out, F. R. Weller, E. P. Mul, H. M. Jansen and J. S. van der Zee: Influx of neutrophils into the airway lumen at $4 \mathrm{~h}$ after segmental allergen challenge in asthma. Int Arch Allergy Immunol, 119(1), 45-53 (1999)

56. C. Pilette, J. N. Francis, S. J. Till and S. R. Durham: CCR4 ligands are up-regulated in the airways of atopic asthmatics after segmental allergen challenge. Eur Respir J, 23(6), 876-84 (2004)

57. F. Sallusto, C. R. Mackay and A. Lanzavecchia: Selective expression of the eotaxin receptor CCR3 by human T helper 2 cells. Science, 277(5334), 2005-7 (1997)

58. B. Lamkhioued, P. M. Renzi, S. Abi-Younes, E. A. Garcia-Zepada, Z. Allakhverdi, O. Ghaffar, M. D. Rothenberg, A. D. Luster and Q. Hamid: Increased expression of eotaxin in bronchoalveolar lavage and airways of asthmatics contributes to the chemotaxis of eosinophils to the site of inflammation. J Immunol, 159(9), 4593-601 (1997)

59. S. Ying, Q. Meng, K. Zeibecoglou, D. S. Robinson, A. Macfarlane, M. Humbert and A. B. Kay: Eosinophil chemotactic chemokines (eotaxin, eotaxin-2, RANTES, monocyte chemoattractant protein-3 (MCP-3), and MCP4 ), and C-C chemokine receptor 3 expression in bronchial biopsies from atopic and nonatopic (Intrinsic) asthmatics. $J$ Immunol, 163(11), 6321-9 (1999)

60. S. Ying, D. S. Robinson, Q. Meng, J. Rottman, R. Kennedy, D. J. Ringler, C. R. Mackay, B. L. Daugherty, M. S. Springer, S. R. Durham, T. J. Williams and A. B. Kay: Enhanced expression of eotaxin and CCR3 mRNA and protein in atopic asthma. Association with airway hyperresponsiveness and predominant co-localization of eotaxin mRNA to bronchial epithelial and endothelial cells. Eur J Immunol, 27(12), 3507-16 (1997)
61. A. M. Das, K. G. Vaddi, K. A. Solomon, C. Krauthauser, X. Jiang, K. W. McIntyre, X. X. Yang, E. Wadman, P. Welch, M. Covington, D. Graden, K. Yeleswaram, J. M. Trzaskos, R. C. Newton, S. Mandlekar, S. S. Ko, P. H. Carter and P. Davies: Selective inhibition of eosinophil influx into the lung by small molecule CC chemokine receptor 3 antagonists in mouse models of allergic inflammation. J Pharmacol Exp Ther, 318(1), 4117 (2006)

62. G. V. De Lucca, U. T. Kim, B. J. Vargo, J. V. Duncia, J. B. Santella, 3rd, D. S. Gardner, C. Zheng, A. Liauw, Z. Wang, G. Emmett, D. A. Wacker, P. K. Welch, M. Covington, N. C. Stowell, E. A. Wadman, A. M. Das, P. Davies, S. Yeleswaram, D. M. Graden, K. A. Solomon, R. C. Newton, G. L. Trainor, C. P. Decicco and S. S. Ko: Discovery of CC chemokine receptor-3 (CCR3) antagonists with picomolar potency. J Med Chem, 48(6), 2194-211 (2005)

63. T. Morokata, K. Suzuki, Y. Masunaga, K. Taguchi, K. Morihira, I. Sato, M. Fujii, S. Takizawa, Y. Torii, N. Yamamoto, M. Kaneko, T. Yamada, K. Takahashi and Y. Shimizu: A novel, selective, and orally available antagonist for CC chemokine receptor 3. J Pharmacol Exp Ther, 317(1), 244-50 (2006)

64. K. Suzuki, T. Morokata, K. Morihira, I. Sato, S. Takizawa, M. Kaneko, K. Takahashi and Y. Shimizu: A dual antagonist for chemokine CCR3 receptor and histamine H1 receptor. Eur J Pharmacol, 563(1-3), 224-32 (2007)

65. D. Lezcano-Meza, M. C. Negrete-Garcia, M. DanteEscobedo and L. M. Teran: The monocyte-derived chemokine is released in the bronchoalveolar lavage fluid of steady-state asthmatics. Allergy, 58(11), 1125-30 (2003)

66. P. Panina-Bordignon, A. Papi, M. Mariani, P. Di Lucia, G. Casoni, C. Bellettato, C. Buonsanti, D. Miotto, C. Mapp, A. Villa, G. Arrigoni, L. M. Fabbri and F. Sinigaglia: The C-C chemokine receptors CCR4 and CCR8 identify airway $\mathrm{T}$ cells of allergen-challenged atopic asthmatics. J Clin Invest, 107(11), 1357-64 (2001)

67. P. Vijayanand, K. Durkin, G. Hartmann, J. Morjaria, G. Seumois, K. J. Staples, D. Hall, C. Bessant, M. Bartholomew, P. H. Howarth, P. S. Friedmann and R. Djukanovic: Chemokine receptor 4 plays a key role in $\mathrm{T}$ cell recruitment into the airways of asthmatic patients. $J$ Immunol, 184(8), 4568-74 (2010)

68. K. Kurashima, M. Fujimura, S. Myou, K. Kasahara, H. Tachibana, N. Amemiya, Y. Ishiura, N. Onai, K. Matsushima and S. Nakao: Effects of oral steroids on blood CXCR3+ and CCR4+ $\mathrm{T}$ cells in patients with bronchial asthma. Am J Respir Crit Care Med, 164(5), 754-8 (2001)

69. K. Hirahara, L. Liu, R. A. Clark, K. Yamanaka, R. C. Fuhlbrigge and T. S. Kupper: The majority of human peripheral blood CD4+CD25highFoxp3+ regulatory $\mathrm{T}$ cells 
bear functional skin-homing receptors. J Immunol, 177(7), 4488-94 (2006)

70. A. D. Luster and A. M. Tager: T-cell trafficking in asthma: lipid mediators grease the way. Nat Rev Immunol, 4(9), 711-24 (2004)

71. K. Mutalithas, C. Guillen, C. Day, C. E. Brightling, I. D. Pavord and A. J. Wardlaw: CRTH2 expression on T cells in asthma. Clin Exp Immunol, 161(1), 34-40 (2010)

72. H. Hirai, K. Tanaka, O. Yoshie, K. Ogawa, K. Kenmotsu, Y. Takamori, M. Ichimasa, K. Sugamura, M. Nakamura, S. Takano and K. Nagata: Prostaglandin D2 selectively induces chemotaxis in $\mathrm{T}$ helper type 2 cells, eosinophils, and basophils via seven-transmembrane receptor CRTH2. J Exp Med, 193(2), 255-61 (2001)

73. L. Xue, S. L. Gyles, F. R. Wettey, L. Gazi, E. Townsend, M. G. Hunter and R. Pettipher: Prostaglandin D2 causes preferential induction of proinflammatory Th2 cytokine production through an action on chemoattractant receptor-like molecule expressed on Th2 cells. J Immunol, 175(10), 6531-6 (2005)

74. E. A. Tivol, F. Borriello, A. N. Schweitzer, W. P. Lynch, J. A. Bluestone and A. H. Sharpe: Loss of CTLA-4 leads to massive lymphoproliferation and fatal multiorgan tissue destruction, revealing a critical negative regulatory role of CTLA-4. Immunity, 3(5), 541-7 (1995)

75. P. Waterhouse, J. M. Penninger, E. Timms, A. Wakeham, A. Shahinian, K. P. Lee, C. B. Thompson, H. Griesser and T. W. Mak: Lymphoproliferative disorders with early lethality in mice deficient in Ctla-4. Science, 270(5238), 985-8 (1995)

76. P. W. Hellings, P. Vandenberghe, A. Kasran, L. Coorevits, L. Overbergh, C. Mathieu and J. L. Ceuppens: Blockade of CTLA-4 enhances allergic sensitization and eosinophilic airway inflammation in genetically predisposed mice. Eur J Immunol, 32(2), 585-94 (2002)

77. D. T. Deurloo, B. C. van Esch, C. L. Hofstra, F. P. Nijkamp and A. J. van Oosterhout: CTLA4-IgG reverses asthma manifestations in a mild but not in a more "severe" ongoing murine model. Am J Respir Cell Mol Biol, 25(6), 751-60 (2001)

78. A. Keane-Myers, W. C. Gause, P. S. Linsley, S. J. Chen and M. Wills-Karp: B7-CD28/CTLA-4 costimulatory pathways are required for the development of $\mathrm{T}$ helper cell 2 -mediated allergic airway responses to inhaled antigens. $J$ Immunol, 158(5), 2042-9 (1997)

79. S. J. Krinzman, G. T. De Sanctis, M. Cernadas, D. Mark, Y. Wang, J. Listman, L. Kobzik, C. Donovan, K. Nassr, I. Katona, D. C. Christiani, D. L. Perkins and P. W. Finn: Inhibition of $\mathrm{T}$ cell costimulation abrogates airway hyperresponsiveness in a murine model. J Clin Invest, 98(12), 2693-9 (1996)
80. P. A. Padrid, M. Mathur, X. Li, K. Herrmann, Y. Qin, A. Cattamanchi, J. Weinstock, D. Elliott, A. I. Sperling and J. A. Bluestone: CTLA4Ig inhibits airway eosinophilia and hyperresponsiveness by regulating the development of Th1/Th2 subsets in a murine model of asthma. Am J Respir Cell Mol Biol, 18(4), 453-62 (1998)

81. S. Tsuyuki, J. Tsuyuki, K. Einsle, M. Kopf and A. J. Coyle: Costimulation through B7-2 (CD86) is required for the induction of a lung mucosal $\mathrm{T}$ helper cell 2 (TH2) immune response and altered airway responsiveness. $J$ Exp Med, 185(9), 1671-9 (1997)

82. A. J. Van Oosterhout, C. L. Hofstra, R. Shields, B. Chan, I. Van Ark, P. M. Jardieu and F. P. Nijkamp: Murine CTLA4-IgG treatment inhibits airway eosinophilia and hyperresponsiveness and attenuates IgE upregulation in a murine model of allergic asthma. Am J Respir Cell Mol Biol, 17(3), 386-92 (1997)

83. C. M. Deppong, A. Parulekar, J. S. Boomer, T. L. Bricker and J. M. Green: CTLA4-Ig inhibits allergic airway inflammation by a novel CD28-independent, nitric oxide synthase-dependent mechanism. Eur J Immunol (2010)

84. J. M. Kremer: Selective costimulation modulators: a novel approach for the treatment of rheumatoid arthritis. $J$ Clin Rheumatol, 11(3 Suppl), S55-62 (2005)

85. M. E. Keir and A. H. Sharpe: The B7/CD28 costimulatory family in autoimmunity. Immunol Rev, 204, 128-43 (2005)

86. Y. Agata, A. Kawasaki, H. Nishimura, Y. Ishida, T. Tsubata, H. Yagita and T. Honjo: Expression of the PD-1 antigen on the surface of stimulated mouse $\mathrm{T}$ and $\mathrm{B}$ lymphocytes. Int Immunol, 8(5), 765-72 (1996)

87. H. Nishimura and T. Honjo: PD-1: an inhibitory immunoreceptor involved in peripheral tolerance. Trends Immunol, 22(5), 265-8 (2001)

88. M. Ishida, Y. Iwai, Y. Tanaka, T. Okazaki, G. J. Freeman, N. Minato and T. Honjo: Differential expression of PD-L1 and PD-L2, ligands for an inhibitory receptor PD-1, in the cells of lymphohematopoietic tissues. Immunol Lett, 84(1), 57-62 (2002)

89. S. C. Liang, Y. E. Latchman, J. E. Buhlmann, M. F. Tomczak, B. H. Horwitz, G. J. Freeman and A. H. Sharpe: Regulation of PD-1, PD-L1, and PD-L2 expression during normal and autoimmune responses. Eur J Immunol, 33(10), 2706-16 (2003)

90. Y. Latchman, C. R. Wood, T. Chernova, D. Chaudhary, M. Borde, I. Chernova, Y. Iwai, A. J. Long, J. A. Brown, R. Nunes, E. A. Greenfield, K. Bourque, V. A. Boussiotis, L. L. Carter, B. M. Carreno, N. Malenkovich, H. Nishimura, T. Okazaki, T. Honjo, A. H. Sharpe and G. J. Freeman: PD-L2 is a second ligand for PD-1 and inhibits T cell activation. Nat Immunol, 2(3), 261-8 (2001) 
91. S. Y. Tseng, M. Otsuji, K. Gorski, X. Huang, J. E. Slansky, S. I. Pai, A. Shalabi, T. Shin, D. M. Pardoll and H. Tsuchiya: B7-DC, a new dendritic cell molecule with potent costimulatory properties for T cells. J Exp Med, 193(7), 839-46 (2001)

92. T. Shin, G. Kennedy, K. Gorski, H. Tsuchiya, H. Koseki, M. Azuma, H. Yagita, L. Chen, J. Powell, D. Pardoll and F. Housseau: Cooperative B7-1/2 (CD80/CD86) and B7-DC costimulation of CD4+ T cells independent of the PD-1 receptor. J Exp Med, 198(1), 31-8 (2003)

93. L. M. Francisco, V. H. Salinas, K. E. Brown, V. K. Vanguri, G. J. Freeman, V. K. Kuchroo and A. H. Sharpe: PD-L1 regulates the development, maintenance, and function of induced regulatory T cells. J Exp Med, 206(13), 3015-29 (2009)

94. E. Oflazoglu, D. A. Swart, P. Anders-Bartholo, H. K. Jessup, A. M. Norment, W. A. Lawrence, K. Brasel, J. E. Tocker, T. Horan, A. A. Welcher and D. R. Fitzpatrick: Paradoxical role of programmed death-1 ligand 2 in Th2 immune responses in vitro and in a mouse asthma model in vivo. Eur J Immunol, 34(12), 3326-36 (2004)

95. K. Matsumoto, H. Inoue, T. Nakano, M. Tsuda, Y. Yoshiura, S. Fukuyama, F. Tsushima, T. Hoshino, H. Aizawa, H. Akiba, D. Pardoll, N. Hara, H. Yagita, M. Azuma and Y. Nakanishi: B7-DC regulates asthmatic response by an IFN-gamma-dependent mechanism. $J$ Immunol, 172(4), 2530-41 (2004)

96. N. Watanabe, M. Gavrieli, J. R. Sedy, J. Yang, F. Fallarino, S. K. Loftin, M. A. Hurchla, N. Zimmerman, J. Sim, X. Zang, T. L. Murphy, J. H. Russell, J. P. Allison and K. M. Murphy: BTLA is a lymphocyte inhibitory receptor with similarities to CTLA-4 and PD-1. Nat Immunol, 4(7), 670-9 (2003)

97. M. A. Hurchla, J. R. Sedy, M. Gavrieli, C. G. Drake, T. L. Murphy and K. M. Murphy: B and T lymphocyte attenuator exhibits structural and expression polymorphisms and is highly Induced in anergic CD4+ T cells. J Immunol, 174(6), 3377-85 (2005)

98. P. Han, O. D. Goularte, K. Rufner, B. Wilkinson and J. Kaye: An inhibitory Ig superfamily protein expressed by lymphocytes and APCs is also an early marker of thymocyte positive selection. J Immunol, 172(10), 5931-9 (2004)

99. M. Gavrieli and K. M. Murphy: Association of Grb-2 and PI3K p85 with phosphotyrosile peptides derived from BTLA. Biochem Biophys Res Commun, 345(4), 1440-5 (2006)

100. M. Gavrieli, N. Watanabe, S. K. Loftin, T. L. Murphy and K. M. Murphy: Characterization of phosphotyrosine binding motifs in the cytoplasmic domain of $\mathrm{B}$ and $\mathrm{T}$ lymphocyte attenuator required for association with protein tyrosine phosphatases SHP-1 and SHP-2. Biochem Biophys Res Commun, 312(4), 1236-43 (2003)

101. R. Tao, L. Wang, R. Han, T. Wang, Q. Ye, T. Honjo, T. L. Murphy, K. M. Murphy and W. W. Hancock: Differential effects of B and T lymphocyte attenuator and programmed death-1 on acceptance of partially versus fully MHC-mismatched cardiac allografts. J Immunol, 175(9), 5774-82 (2005)

102. T. Tamachi, N. Watanabe, Y. Oya, S. Kagami, K. Hirose, Y. Saito, I. Iwamoto and H. Nakajima: B and T lymphocyte attenuator inhibits antigen-induced eosinophil recruitment into the airways. Int Arch Allergy Immunol, 143 Suppl 1, 50-5 (2007)

103. M. A. Hurchla, J. R. Sedy and K. M. Murphy: Unexpected role of $\mathrm{B}$ and $\mathrm{T}$ lymphocyte attenuator in sustaining cell survival during chronic allostimulation. $J$ Immunol, 178(10), 6073-82 (2007)

104. L. C. Gonzalez, K. M. Loyet, J. Calemine-Fenaux, V. Chauhan, B. Wranik, W. Ouyang and D. L. Eaton: A coreceptor interaction between the CD28 and TNF receptor family members $\mathrm{B}$ and $\mathrm{T}$ lymphocyte attenuator and herpesvirus entry mediator. Proc Natl Acad Sci USA, 102(4), 1116-21 (2005)

105. J. R. Sedy, M. Gavrieli, K. G. Potter, M. A. Hurchla, R. C. Lindsley, K. Hildner, S. Scheu, K. Pfeffer, C. F. Ware, T. L. Murphy and K. M. Murphy: B and T lymphocyte attenuator regulates $\mathrm{T}$ cell activation through interaction with herpesvirus entry mediator. Nat Immunol, 6(1), 90-8 (2005)

106. K. M. Murphy, C. A. Nelson and J. R. Sedy: Balancing co-stimulation and inhibition with BTLA and HVEM. Nat Rev Immunol, 6(9), 671-81 (2006)

107. S. W. Granger and S. Rickert: LIGHT-HVEM signaling and the regulation of T cell-mediated immunity. Cytokine Growth Factor Rev, 14(3-4), 289-96 (2003)

108. J. Kim, A. C. Myers, L. Chen, D. M. Pardoll, Q. A. Truong-Tran, A. P. Lane, J. F. McDyer, L. Fortuno and R. P. Schleimer: Constitutive and inducible expression of b7 family of ligands by human airway epithelial cells. Am J Respir Cell Mol Biol, 33(3), 280-9 (2005)

109. E. Salik, M. Tyorkin, S. Mohan, I. George, K. Becker, E. Oei, T. Kalb and K. Sperber: Antigen trafficking and accessory cell function in respiratory epithelial cells. Am J Respir Cell Mol Biol, 21(3), 365-79 (1999)

110. C. Deppong, J. M. Degnan, T. L. Murphy, K. M. Murphy and J. M. Green: B and T lymphocyte attenuator regulates $\mathrm{T}$ cell survival in the lung. J Immunol, 181(5), 2973-9 (2008)

111. L. Hongjia, G. Qingling, L. Meiying, W. Weixuan, Z. Lihong, G. Yongsheng, L. Yanli, W. Jinxiang and D. Liang: House dust mite regulate the lung inflammation of 
asthmatic mice through TLR4 pathway in airway epithelial cells. Cell Biochem Funct, 28(7), 597-603 (2010)

112. E. M. Shevach: Mechanisms of foxp3+ T regulatory cell-mediated suppression. Immunity, 30(5), 636-45 (2009)

113. M. A. Curotto de Lafaille, N. Kutchukhidze, S. Shen, Y. Ding, H. Yee and J. J. Lafaille: Adaptive Foxp3+ regulatory $\mathrm{T}$ cell-dependent and -independent control of allergic inflammation. Immunity, 29(1), 114-26 (2008)

114. M. D. Leech, R. A. Benson, A. De Vries, P. M. Fitch and S. E. Howie: Resolution of Der p1-induced allergic airway inflammation is dependent on CD4+CD25+Foxp3+ regulatory cells. J Immunol, 179(10), 7050-8 (2007)

115. I. P. Lewkowich, N. S. Herman, K. W. Schleifer, M. P. Dance, B. L. Chen, K. M. Dienger, A. A. Sproles, J. S. Shah, J. Kohl, Y. Belkaid and M. Wills-Karp: CD4+CD25+ $\mathrm{T}$ cells protect against experimentally induced asthma and alter pulmonary dendritic cell phenotype and function. $J$ Exp Med, 202(11), 1549-61 (2005)

116. W. Chen, W. Jin, N. Hardegen, K. J. Lei, L. Li, N. Marinos, G. McGrady and S. M. Wahl: Conversion of peripheral $\mathrm{CD} 4+\mathrm{CD} 25$ - naive $\mathrm{T}$ cells to $\mathrm{CD} 4+\mathrm{CD} 25+$ regulatory $\mathrm{T}$ cells by TGF-beta induction of transcription factor Foxp3. J Exp Med, 198(12), 1875-86 (2003)

117. J. Kearley, J. E. Barker, D. S. Robinson and C. M. Lloyd: Resolution of airway inflammation and hyperreactivity after in vivo transfer of CD4+CD25+ regulatory $\mathrm{T}$ cells is interleukin 10 dependent. J Exp Med, 202(11), 1539-47 (2005)

118. J. Kearley, D. S. Robinson and C. M. Lloyd: $\mathrm{CD} 4+\mathrm{CD} 25+$ regulatory $\mathrm{T}$ cells reverse established allergic airway inflammation and prevent airway remodeling. $J$ Allergy Clin Immunol, 122(3), 617-24 e6 (2008)

119. H. S. McGee, H. Yagita, Z. Shao and D. K. Agrawal: PD-1 Antibody Blocks Therapeutic Effects of T-regulatory Cells in Cockroach Antigen-induced Allergic Asthma. Am J Respir Cell Mol Biol (2009)

120. X. Chen, J. J. Oppenheim, R. T. Winkler-Pickett, J. R. Ortaldo and O. M. Howard: Glucocorticoid amplifies IL-2dependent expansion of functional FoxP3(+)CD4(+)CD25(+) T regulatory cells in vivo and enhances their capacity to suppress EAE. Eur J Immunol, 36(8), 2139-49 (2006)

121. F. J. Barrat, D. J. Cua, A. Boonstra, D. F. Richards, C. Crain, H. F. Savelkoul, R. de Waal-Malefyt, R. L. Coffman, C. M. Hawrylowicz and A. O'Garra: In vitro generation of interleukin 10-producing regulatory $\mathrm{CD} 4(+)$ $\mathrm{T}$ cells is induced by immunosuppressive drugs and inhibited by $\mathrm{T}$ helper type 1 (Th1)- and Th2-inducing cytokines. J Exp Med, 195(5), 603-16 (2002)

122. V. Brinkmann and C. Kristofic: Regulation by corticosteroids of Th1 and Th2 cytokine production in human CD4+ effector $\mathrm{T}$ cells generated from CD45ROand CD45RO+ subsets. J Immunol, 155(7), 3322-8 (1995)

123. C. Karagiannidis, M. Akdis, P. Holopainen, N. J. Woolley, G. Hense, B. Ruckert, P. Y. Mantel, G. Menz, C. A. Akdis, K. Blaser and C. B. Schmidt-Weber: Glucocorticoids upregulate FOXP3 expression and regulatory $\mathrm{T}$ cells in asthma. J Allergy Clin Immunol, 114(6), 1425-33 (2004)

124. E. J. Peek, D. F. Richards, A. Faith, P. Lavender, T. H. Lee, C. J. Corrigan and C. M. Hawrylowicz: Interleukin-10secreting "regulatory" $\mathrm{T}$ cells induced by glucocorticoids and beta2-agonists. Am J Respir Cell Mol Biol, 33(1), 105-11 (2005)

125. D. F. Richards, M. Fernandez, J. Caulfield and C. M. Hawrylowicz: Glucocorticoids drive human CD8(+) T cell differentiation towards a phenotype with high IL-10 and reduced IL-4, IL-5 and IL-13 production. Eur J Immunol, 30(8), 2344-54 (2000)

126. Y. L. Lin, C. C. Shieh and J. Y. Wang: The functional insufficiency of human CD4+CD25 high T-regulatory cells in allergic asthma is subjected to TNF-alpha modulation. Allergy, 63(1), 67-74 (2008)

127. E. M. Ling, T. Smith, X. D. Nguyen, C. Pridgeon, M. Dallman, J. Arbery, V. A. Carr and D. S. Robinson: Relation of $\mathrm{CD} 4+\mathrm{CD} 25+$ regulatory $\mathrm{T}$-cell suppression of allergendriven T-cell activation to atopic status and expression of allergic disease. Lancet, 363(9409), 608-15 (2004)

128. D. Hartl, B. Koller, A. T. Mehlhorn, D. Reinhardt, T. Nicolai, D. J. Schendel, M. Griese and S. Krauss-Etschmann: Quantitative and functional impairment of pulmonary CD4+CD25hi regulatory T cells in pediatric asthma. J Allergy Clin Immunol, 119(5), 1258-66 (2007)

129. M. Akdis, J. Verhagen, A. Taylor, F. Karamloo, C. Karagiannidis, R. Crameri, S. Thunberg, G. Deniz, R. Valenta, H. Fiebig, C. Kegel, R. Disch, C. B. Schmidt-Weber, K. Blaser and C. A. Akdis: Immune responses in healthy and allergic individuals are characterized by a fine balance between allergen-specific $\mathrm{T}$ regulatory 1 and $\mathrm{T}$ helper 2 cells. $J$ Exp Med, 199(11), 1567-75 (2004)

130. L. J. Smyth, A. Eustace, U. Kolsum, J. Blaikely and D. Singh: Increased airway $\mathrm{T}$ regulatory cells in asthmatic subjects. Chest (2010)

131. J. H. Lee, H. H. Yu, L. C. Wang, Y. H. Yang, Y. T. Lin and B. L. Chiang: The levels of CD4+CD25+ regulatory $\mathrm{T}$ cells in paediatric patients with allergic rhinitis and bronchial asthma. Clin Exp Immunol, 148(1), 53-63 (2007)

132. S. Provoost, T. Maes, Y. M. van Durme, P. Gevaert, C. Bachert, C. B. Schmidt-Weber, G. G. Brusselle, G. F. Joos and K. G. Tournoy: Decreased FOXP3 protein expression in patients with asthma. Allergy, 64(10), 153946 (2009) 
133. Z. Urry, E. Xystrakis, D. F. Richards, J. McDonald, Z. Sattar, D. J. Cousins, C. J. Corrigan, E. Hickman, Z. Brown and C. M. Hawrylowicz: Ligation of TLR9 induced on human IL-10-secreting Tregs by 1alpha,25dihydroxyvitamin D3 abrogates regulatory function. J Clin Invest, 119(2), 387-98 (2009)

134. C. Hawrylowicz, D. Richards, T. K. Loke, C. Corrigan and T. Lee: A defect in corticosteroid-induced IL-10 production in $\mathrm{T}$ lymphocytes from corticosteroid-resistant asthmatic patients. J Allergy Clin Immunol, 109(2), 369-70 (2002)

135. E. Xystrakis, S. Kusumakar, S. Boswell, E. Peek, Z. Urry, D. F. Richards, T. Adikibi, C. Pridgeon, M. Dallman, T. K. Loke, D. S. Robinson, F. J. Barrat, A. O'Garra, P. Lavender, T. H. Lee, C. Corrigan and C. M. Hawrylowicz: Reversing the defective induction of IL-10-secreting regulatory $\mathrm{T}$ cells in glucocorticoid-resistant asthma patients. J Clin Invest, 116(1), 146-55 (2006)

Abbreviations: APC, antigen presenting cell; BAL, bronchoalveolar lavage; BALF, bronchoalveolar lavage fluid; BTLA, B and T lymphocyte attenuator; CTLA4, cytotoxic T-lymphocyte antigen 4; EAE, experimental autoimmune encephalomyelitis; GVHD, graft versus host disease; HVEM, herpes virus entry mediator; ICOS, inducible costimulator; LTB4, leukotriene B4; MCP-3, monocyte specific chemokine-3; mDC, myeloid dendritic cell; MIP-1-alpha, macrophage inflammatory protein-1alpha; NK, natural killer; PBMC, peripheral blood mononuclear cell; PD-1, programmed death receptor; PGD2, prostaglandin D2; RANTES, Regulated upon activation, normal T-cell expressed and secreted; TNFR, tumor necrosis factor receptor; TRAIL, TNF-related apoptosis-inducing ligand;

Key Words: Asthma, T cells, Inflammation, Lung, Review

Send correspondence to: Jonathan M. Green, Division of Pulmonary and Critical Care Medicine, Department of Internal Medicine, Box 8052 CSRB, 660 S. Euclid Avenue, St. Louis, MO 63110, Tel: 314-747-3591, Fax: 314-3628987, E-mail: jgreen@wustl.edu 